\title{
From 25 Years Ago
}

\section{Range Management in the Decade Ahead}

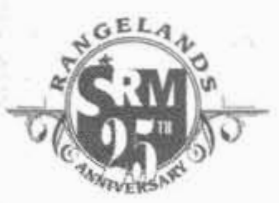

As a tribute to the $25^{\text {th }}$ anniversary of "Rangelands," we are including comments and articles from past SRM events and issues of the publication. These brief glimpses back in time offer a reminder of where we've been and how far we've come.

This article is excerpted from an address by U.S. Senator Malcolm Wallop from Wyoming at the Annual Meeting of the Society for Range Management at Casper, Wyoming, February 12, 1979.

\section{By The Honorable Malcom Wallop}

Since the discovery that "our great American desert" had value, this nation's rangeland has been fiercely contested property; and its value as a natural resource has changed radically and rapidly in the century since California Joe, an old Dakota Guide, described it as "gold from the grassroots up."

Now, we know it also represents "gold from the grass roots down." It's a source of forage, energy resources, wildlife habitat, recreation, watershed, and just plain real estate to accommodate urban sprawl. The ecology of the range hasn't changed much - but we have become more demanding. So, the social and economic conflicts which erupted into the range wars of the 1870's have evolved into political, economic, and yes, philosophical wars of the 1970's.

And if we look back at the history of our rangeland, we find that though it is finite, it can be resilient if we manage it properly. Multiple use is desirable, and on most rangelands, inevitable. But it is totally dependent upon proper, rational professional management.

Let's look into the role of the United States Congress in several matters concerning rangeland management. In theory, it's Congress' responsibility to provide the legislation and appropriations necessary to protect the range yet promote its productivity. In practice, the public range has been victimized by everything from benign neglect to bumbling overkill.

The Rangeland Improvement Act of 1978 clearly represents progress.

- It provides $\$ 360$ million over 20 years; a mini- mum of $80 \%$ in on-ground improvements and $15 \%$ to hire and train new qualified range management personnel.

- It bases grazing fees on a formula related to production costs and market prices.

- It addresses the responsibility of the Bureau of Land Management for wild horses and burro management so that we can restore the desired ecological balance among wildlife, domestic livestock, and vegetation.

The Act is a positive sign - that we as a nation are interested in rangeland, recognize existing problems, and will follow professional recommendations to correct them.

A second important trend is apparent in the detailed provisions of this Act. Congress has clearly limited discretionary, administrative authority. We are conscious of the disparity that has occurred in the past between legislative intent and administrative implementation. In efforts to provide flexibility, the result has all too often undermined the original purpose of the law. This criticism applies to much legislation. Consequently, I can only hope that we are going to see increased Congressional oversight in rangeland management - in all federal management - in the 1980s.

RARE II is another federal agency effort which will demand considerable Congressional oversight and which will impact public rangelands. As you know, National Forests and National Grasslands encompass 103 million acres or $41 \%$ of this nation's publicly owned rangeland. The now-famous Forest RARE II Roadless Area Review and Evaluation 
identified some 62 million acres in 38 states which were inventoried and evaluated for their wilderness potential. The final EIS (Environmental Impact Statement) from the Forest Service recommends 15 million acres for wilderness, 36 million acres for multiple use, and 11 million acres for further planning. This last category of lands must go through the land management process before changes in the resource management can occur.

Frankly, one of my major concerns about RARE II has been that it be completed on time, and that the smallest possible proportion of lands be allocated for further planning so as not to leave them and their users in a state of limbo. The Forest Service is, I think, to be commended for trying to achieve these goals, although I know there are a number of legitimate concerns about the actual RARE II recommendations. I would have hoped this could serve as a precedent with the far more extensive Bureau of Land Management wilderness review. But my skepticism remains.

Here, we're talking about 450 million acres and a 12-year time frame for final resolution. Two optimistic notes are, if they are honored: the ostensible flexible policy permitting continued multiple use on public lands and some release from further wilderness criteria by July, 1980. However, in both studies, as a member of the Senate Energy and Natural Resources Committee, I can state we all intend to give oversight high priority. We can and must expedite decisions on RARE II's further planning category in particular and the BLM study in general.

The debate over RARE II wilderness areas will serve as an excellent educational exercise for Eastern senators. Lack of understanding of Western lands and needs is understandable but nonetheless bodes ill for public policymaking. We now have an active bi-partisan coalition of 34 senators from the 17 western states laboring and lobbying and logrolling as necessary to educate our Eastern colleagues. The Rangeland Improvement Act is a sign of our success - we are making a dent. They know that somewhere between St. Louis, San Antonio, and San Francisco a different ecosystem and lifestyle exist.

My hope is to bring RARE II eastern wilderness areas up for consideration first. This will increase Eastern appreciation of our problems and pressure as well as secure wilderness in the geographic area where it's most threatened and needed. By applying heat, we may also achieve light.

In another area, rangeland management and federal coal policies have at times been at odds with one another. And given the tremendous boom in mining activity, it's not hard to understand why.

We have come a long way in recent years. The unique reclamation problems associated with strip mining on semiarid Western rangelands are beginning to be understood. Thanks to the contributions of you men and women in the range management profession, mined land reclamation is changing from an art to a science. The Surface Mining Control and Reclamation Act of 1977 mandates certain reclamation standards. Its provisions require surface mining operations to restore the land to a condition capable of supporting prior uses. The approximate original contour of the area being mined must be restored. Topsoil must be replaced after mining. And care must be taken to minimize the disturbances to the quality and quantity of water in surface and underground systems. The new act also creates a reclamation tax to be used to reclaim abandoned mine sites. Again, Congress has the oversight responsibility to insure those concepts are achieved.

Let me conclude by acknowledging that my remarks have focused on but a few of the many challenges facing rangeland management. The critical point is that we are making progress.

Positive trends are evident which should advance your efforts - and your influence - in the decade ahead.

- There is a growing awareness in Congress of the importance of rangeland and the need to improve, preserve, and protect it through policies which promote proper management. 
- Increased Congressional oversight should bring a far more precise efficient correlation between legislative intent and administration implementation.

- An increased realism is sweeping the country affecting attitudes on every subject from environmental protection to government regulation. America is coming of age and recognizing that we must make critical choices to maintain our standard of living and our environment.

We are going to have to rely less on spontaneous momentum, more on professional management, and thus, you in range management represent the wave of the future as well as the strength of the past. You in the Society for Range Management will play an increasingly important role in policy decisions. You will largely determine the direction of rangeland management in the 1980's. I can think of no organization more dedicated or qualified to assure this responsibility. Your competence has earned our confidence.

As a Senator, a Rancher, and an American, I salute you!

Reprinted from Rangelands, June 1979.

\section{Showing the Way}

oCRP Grasses

- Sharpshooter

Buffalograss

Native and

Introduced

Grasses

-Custom Seed

Mixes

-Turf Grasses

-Reclamation

Grasses

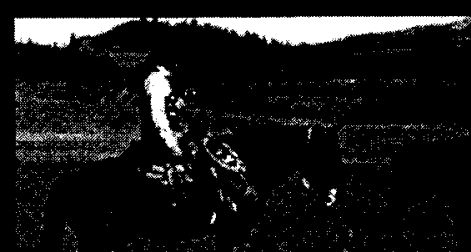

*Wildlife Mixes

- Field Seeds

*Certitied Wheat

$\rightarrow$ llybrid Forage

Sorghum

- Sorghum

Sudangrass

lybrids

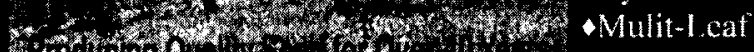

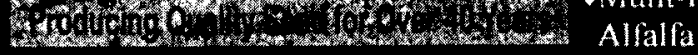

-Wildlowers
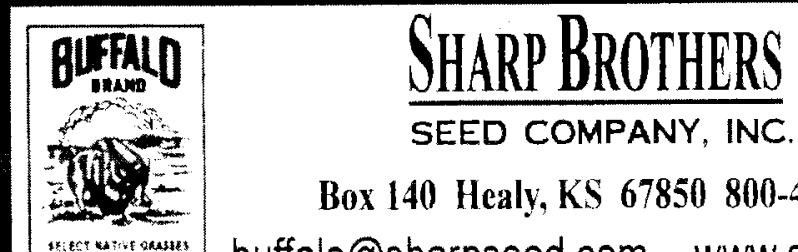

Box 140 Healy, KS 67850 800-462-8483

buffalo@sharpseed.com www.sharpseed.com 